\title{
Muslim Immigrants, Public Religion and Developments towards a Post-Secular Finnish Welfare State
}

\author{
Tuomas Martikainen
}

\begin{abstract}
The article addresses the question whether, with Finland as the case, the Nordic welfare state is undergoing profound change under the influence of neo-liberal global economics and new forms of governance. The article starts with a critique of Nancy Foner and Richard Alba's (2008) comparison of the position of Muslims in the USA and Western Europe and claims that their comparison does not take into account more recent changes in the ways how West European states deal with religion. Instead the article argues that state-religion relations have been influenced by the neo-liberal restructuring of society and it presents an alternative way to look at state-religion relations. It is claimed the societal location of religion is now better understood within the context of civil society rather than an institutional sphere of its own.
\end{abstract}

Muslim immigrants and their offspring have been at the centre of major scholarly attention in Western societies for some time, and they have been studied from a variety of social scientific theoretical positions. In the 2000s, the input of political science in the study of Muslim minorities has become stronger and in this context statechurch/religion relations have been seen as significant in explaining differences between immigrant receiving countries and how they handle their immigrant-origin Muslim minorities (for overviews, see Fetzer \& Soper 2005; Maussen 2007). Much of the research starts from a standpoint that presumes a modern, secularized nation-state, where immigrants and the Religious Other are an anomaly that the state attempts to 
accommodate and regulate through various policies and programmes. States are expected to base their policies in their respective national traditions, which differ markedly (Robbers 2005) but share an ethos of secularism. In this context, Islam is often portrayed as including non-secularized elements that pose a problem to preexisting societal practices (Casanova 2007).

The role of the state is obviously the larger the more interventionist it is in its nature. The Scandinavian or Nordic welfare states are known for their spirit of social engineering, where inclusion in the labour force has been their main target combined with an ethos of social class and gender equality. ${ }^{1}$ The general labour market orientation is combined with financial support and co-operation with civil society for the common good, and hence there is no clear boundary between the third sector of associations and the state apparatus. This is in marked contrast with the AngloAmerican and, especially, the US tradition, where the state has had a more restricted role and civil society more autonomy. While these differences should not be exaggerated - as the state nevertheless sets the rules of the game and directs nongovernmental actors through legal and other means as well as by the allocation of resources - they are of importance as mentalities of rule and regulation, and also visible in scholarly discussions as normative presumptions. Nevertheless, there is some recent scholarship that argues that during the last thirty years many states around the world have created new types of bonds with civil society organizations, including the UK and the USA, so that civil society's actual independence of state concerns can be questioned in many cases (Sinha 2005).

The focus of this article is the incorporation of Muslim immigrants in the context of the changing Finnish welfare state. It takes as its main discussion partner Nancy Foner and Richard Alba's (2008) article, 'Immigrant Religion in the U.S. and Western Europe: Bridge or Barrier to Inclusion?'. Foner and Alba's text is selected here because it summarizes well the results and spirit of many studies on the topic of immigration,

\footnotetext{
${ }^{1}$ See the introductory chapter to this special issue by Ulrika Mårtensson.
} 
integration and Islam, and engages in transatlantic academic debate of the role of religion in immigrant social integration. Here I will argue, however, that Foner and Alba's position rests on problematic theoretical grounds that do not take enough into account the changes in welfare state structures since the 1980s and, hence, provides a partial view on the state-civil society-religion dynamics in the era of neoliberal globalization. Foner and Alba also tend to overemphasize the differences between Muslims and other immigrants. Consequently, this article starts with a presentation of Foner and Alba's analysis and proceeds to discuss changes in the Finnish welfare state. After that, the focus turns to immigrant Muslims and examples of new forms of public engagement with Muslims, the state and civil society in Finland will be presented. The final section of the article engages in discussion of Islam as a public religion in postsecular Finland, with reference to José Casanova's (1994) and Jürgen Habermas' (2008) views on the nature of contemporary religion. Casanova and Habermas are selected because both are referred to extensively in current theoretical debates on religion and modernity.

\section{Foner and Alba on Immigrant Religion in Western Europe and the United States}

Nancy Foner and Richard Alba are both senior US scholars in ethnic and migration studies. Their article 'Immigrant Religion in the U.S. and Western Europe: Bridge or Barrier to Inclusion?' was published in International Migration Review in June 2008. The article aims to explain "why the views of immigrant religion are so different on the two sides of the Atlantic and how they correspond with on-the-ground social realities' (Foner \& Alba 2008: 361). The authors argue 'that the difference is anchored in whether or not religion as belief system, institution, and community can play a major role for immigrants and the second generation as a bridge to inclusion in the new society' (Foner \& Alba 2008: 361). The focus of the article is the USA, France, Germany, Britain and the Netherlands, but they claim that 'much of what we say applies to Western European countries generally' (Foner \& Alba 2008: 361). Hence, their observations and arguments should also be valid in Finland. 
According to Foner and Alba, religion is generally viewed as something positive in the USA. Among other things, it helps newcomers to find a positive community that brings many kinds of benefits to participants, including help to reshape their identities and support the socialization of their children. Moreover, in immigrant religious communities new immigrants can learn necessary and useful civic skills by taking part in extra-religious activities provided by religious organizations. Quoting Diana Eck, the authors describe American immigrant congregations as 'training grounds in participatory democracy' (Foner \& Alba 2008: 364-5). In short, 'religion helps to turn immigrants into Americans and gives them and their children a sense of belonging or membership in the United States' (Foner \& Alba 2008: 365). In this manner, Foner and Alba draw attention to the great significance played by religious organizations which represent virtually every immigrant religion.

In Europe, where, following Foner and Alba, Islam is the predominant immigrant religion, the picture is different. Muslims are considered with suspicion, if not with outright hostility, and they are suspected of constituting a threat to 'the liberal values of European states' (Foner \& Alba 2008: 369). Muslims are overall portrayed as discriminated against and as facing prejudice, and their religio-cultural practices are met with mistrust. Again, according to Foner and Alba, public representations of Islam and Muslims are dominated by such topics as the oppression of women, speculations about the creation of parallel societies and Muslims living on social benefits. Islam is cast as a religion that generates conflicts of various kinds; for example, Muslims are said to be increasingly viewed as having 'oppositional identities' (Foner \& Alba 2008: 373) and as being associated with radicalization and terrorism. We may conclude that Foner and Alba's representation of Muslims in Europe focuses on the negative and conflictual public visibility of Islam, and problems with public authorities and structural or overt discrimination against Muslims, but they do not address the role of religious institutions in social integration with reference to Europe in the same detailed way as they did with reference to the USA. 
The apparent dissonance between the US and European experiences was something that Foner and Alba assumed and set out to explain. In the article they highlight three sets of reasons, which even imply a degree of causality. First, whereas in the USA Muslims constitute only a small segment of all immigrants, in Europe Muslims are the largest post-war religious minority. European Muslims are associated with and overrepresented among the less successfully integrated immigrants, as they are to a large extent less skilled labour migrants or their children, ${ }^{2}$ which is a major contrast to the more prosperous and highly skilled US Muslims. Second, being religious is socially approved in the US, while religion is considered with suspicion in Europe. Hence, public religious claims are not automatically acknowledged in Europe and their legitimacy is often questioned. Third, the institutionalization of religion is different in the US and Europe. While Foner and Alba note differences in church-state relations between various European countries, they claim that Muslims have it more difficult in Europe if the comparison is made with historical established churches, which in most cases have strong connections to national identity and the state. ${ }^{3}$ For these reasons, the European system has much more inbuilt potential for conflicts than the US model. In sum, Foner and Alba conclude that 'religious similarity between natives and immigrants, historically rooted institutional structures, and the religiosity of the native population' (Foner \& Alba 2008: 383-4) explain the differences in the degree of welcoming immigrant religions to Europe and the US. The authors also note that

because the social science literature inevitably reflects the concerns and realities in the societies under study, we can also expect social science work on immigrant religion to continue to be characterized by the patterns we have described here, with an emphasis on its positive role in immigrant adjustment and assimilation in the United States and its links to the difficulties of incorporating Muslim

\footnotetext{
${ }^{2}$ Foner \& Alba 2008: 374-6. The authors do not mention refugees and asylum seekers of Muslim background, even though they constitute a major share of Muslims in many European countries. Nor do they take into account other reasons of migration, and their eventual implications for social integration.

${ }^{3}$ A similar stance is shared, among others, by Casanova 2007.
} 
immigrants and their children into Western European societies. (Foner \& Alba 2008: 387)

In the following, some of Foner and Alba's central arguments will be analysed from the perspective of developments in Finland. As that article covers many topics, it is not possible to take all relevant issues into account here, and the commentary will focus on the religious background of immigrants and historically rooted institutional structures. ${ }^{4}$ These will be put both in a historical as well as contemporary context of the Finnish welfare state, to which we shall turn next.

\section{The Restructuration of the Finnish Welfare State and Religion}

The general development of the Scandinavian welfare states is described in the introductory chapter of this special issue. In the following, the focus is on recent changes in the Finnish welfare state, including simultaneous-but not coincidentalchanges in state-church/religion relationships. The perspective pursues current discussions of governance as something broader and more widely encompassing than government, a scholarly trend which in itself hints at the erosion of previous social structures (Kjær 2007: 7) As Anne Mette Kjær (2004: 19) notes:

In public administration, the governance debate is about changes that have taken place in the public sector since the 1980s. From a model based on Weberian principles of hierarchy, neutrality and career civil servants, public sector reforms introduced other models of governing: those of markets and networks.

In Finland, the turn of the 1990s marked the end of the Cold War era, and the fall of the Soviet Union allowed more political flexibility for Finnish decision-makers, developments which eventually led to more open borders and changes in all sectors of society. Until then, Finnish decision-makers were careful not to upset Soviet leaders,

\footnotetext{
4 At the time of writing this article, there were no available studies comparing the religiosity of immigrants and natives in Finland, so it was not possible to provide data on that matter.
} 
even though the country was independent. The eventual restructuration of the Finnish welfare state has its roots in the rapid internationalization of Finnish society, including the growing importance of the global economy and Europeanization. Finland became a member state of the European Union in 1995.

Some Finnish social scientists have described the welfare state transition as a move from a 'planning economy' to a 'competition economy' (Alasuutari 2006), the latter captured in notions such as 'competitiveness society' (Heiskala 2006) and 'project society' (Sulkunen 2006). Risto Heiskala (2006: 37) summarizes some central aspects of the transformation as follows: The aim of the state has shifted from regional and social equality to economic efficiency, innovation and economic growth, and citizens are increasingly conceived of as customers. Governmental co-ordination has moved from hierarchical planning to market mechanisms, including network management and privatization. Previous homogenous cultural values and preferences, collectivism and national protectionism have been replaced by heterogeneity, individualism, cultural openness, and international competition.

Key developments in the competitiveness society include new public management, outsourcing and privatization of welfare services, and the growth of projects and programmes as new forms of governance. Major administrative changes of state structures are undertaken on a regular basis, with the result that institutional boundaries are constantly redrawn, and enduring structures have been replaced, eroded or complemented by more temporary and market-based solutions. The extent and nature of these reforms is difficult to analyse in Finland as well as internationally, because of the complex ways in which they overlap with traditional societal sectors. As Brenner et al. (2010: 189) note, 'market-oriented regulatory reform (...) [is] associated with unpredictable "layering" effects in relation to inherited institutional landscapes'. The analysis of these changes must be done on a case by case basis, because the changes take different forms in different social structures, at the same time as they are embedded in 'transnational fields of policy transfer' (Brenner et al. 2010: 189). Also the role of legal practice has changed, with law becoming increasingly important in solving various 
kinds of conflicts, including socio-cultural ones, a development that resonates with the contractual nature of capitalism. Or, as Ran Hirschl (2004: 71, italics in original) frames it, 'over the past two decades the world has witnessed an astonishingly rapid transition to what may be called juristocracy'.

The Finnish restructuration is part of a global trend of neoliberal policies, whereby the state to an extent retreats from some of its previous societal core functions, or at least redefines its role in service provision, and opens new spaces for market forces to operate (Arestis \& Sawyer 2005; MacGregor 2005). The roots of these developments are the new rules and regulations of global economy that emerged in the late 1970s, and which became mainstream in the following decade. The state's retreat from the role of sole caretaker of the nation entailed growing expectations of other sectors of society to deliver not only services and goods but also identities and forms of belonging. Consequently, we have witnessed an increase of public debates about social capital and civil society, where associations and other voluntary organizations are expected to take a more prominent position than before in creating 'social cohesion' and general welfare (Kjær 2004: 4; Rathgeb \& Smyth 2010: 274). Simultaneously, the Evangelical Lutheran majority church in Finland has redefined its identity from a folk church to a moral voice in civil society, which includes taking a more critical stance in relation to the state than previously.

While changes such as those just described have been under investigation since the 1980s in the social sciences, related changes in state-church/religion relations have not been of major interest in Finland. ${ }^{5}$ This has several reasons. Firstly, secularization

\footnotetext{
5 The lack of interest is not specific to Finland, but seems to apply internationally as well. However, I shall leave aside the international scholarly dimension in this article, as it deserves a thorough analysis of its own. Recently, however, several academic currents in the study of contemporary religion are increasingly sensitive to the restructuration of the state and its effects on religion. These include the role of churches in service provision, the study of faith based organizations and commodification and marketization of religion. See, Martikainen \& Gauthier 2013.
} 
theory is still the dominant paradigm in mainstream analyses of religion and society in Finland. From that perspective nothing dramatic has happened, even though an increasing role of the Evangelical Lutheran Church of Finland in welfare provision and various networks has been noted, as well as the Church's new public visibility (Pessi 2010). This is related to the dominant idea of functional differentiation as a key aspect of secularization, which misses the cross-sectoral nature of current governance reforms, where networks and other temporary solutions are of increasing importance. As Matthias Koenig (2009: 295) notes, 'a linear theory of functional differentiation provides unsatisfactory explanations of the politics of religious diversity'.

Second, since religious changes occur, as it were, on the fringes of institutional power, they have been viewed as unimportant or marginal. This might explain why there is only peripheral interest in minority religions and religious diversity as a challenge to the status quo, as well as in developments inside the dominant Evangelical Lutheran Church. ${ }^{6}$ Processes of internal differentiation have often been viewed rather as examples of classical secularization than as new, emerging forms of religious practice and belief. Even legislative changes as discussed below appear minor in the context of traditional secularization theory, and it is only when a variety of variables are taken into account that a different picture starts to emerge, as demonstrated by ongoing research projects. ${ }^{7}$

As indicated in the Introduction chapter, the Lutheran and Orthodox Churches in Finland have historically had special rights that granted them wide autonomy, ${ }^{8}$ a

\footnotetext{
${ }^{6}$ The main exception to this is interest in the Lutheran Churches' increasing role in service provision, which is a growing field of study in Finland and other Nordic countries. See, Bäckström \& Davie 2010.

${ }^{7}$ For example, both the 'The Role of Religion in the Public Sphere: A Comparative Study of the Five Nordic Countries’ (in Finland: Church Research Institute, 2009-2013, http://www.kifo.no/index.cfm?id=266100) and the 'Post-Secular Culture and a Changing Religious Landscape’ (Åbo Akademi University, 2010-2014, http://web.abo.fi/fak/hf/relvet/pccr/) essentially deal with issues that are at the core of welfare state reform and its impact on religion in the public sphere.

${ }^{8}$ In 2008, 80, 7\% of Finns were members of the Evangelical Lutheran Church, 1.1\% of the Finnish Orthodox Church, $1.3 \%$ of other registered religious organizations and $16.9 \%$ did not belong to any
} 
privileged position and closeness to secular decision makers. Minority religions and the non-religious were granted their rights in the Religious Freedom Act of 1922, but these groups remained at the margins of society until recently. ${ }^{9}$ Religious pluralism has gradually grown since the establishment of religious freedom and, especially since the 1990s, there has been a qualitative and quantitative leap in religious diversity. This is related both to the increasing international mobility of Finns and increasing immigration, which were also taken into account in the process leading to the reform of the Religious Freedom Act in 2003, 'The religio-political situation has changed and, due to internationalization, Finland has also religiously changed to a more multicultural country $^{, 10}$ (Ministry of Education 2001: 19). The new act changed in spirit from negative to positive freedom of religion, and improved the position of minority religions, for instance, in religious education in schools. The planning committee also suggested public financial support for minority religions, which eventually took place in 2008.

To summarize this brief sketch of change in the Finnish welfare state, we can conclude that the state itself has transformed from a paternalistic caretaker to a professional manager, and the state apparatus is increasingly organized via markets and networks. Simultaneously, historical institutional structures are changing, and new, often temporary, alliances formed. Only a few of these changes have directly affected the formal and legal position of religion. Those that have include a growing separation between the state and the majority churches in the 1990s and a reform of religious freedom legislation - affecting all other organized religions - in the 2000s. Beyond that there are signs that religious organizations of many faiths are increasingly becoming part of local and national networks, and co-operating with secular organizations. These

religion. The share of Orthodox has always been quite low, and the Lutheran Church is much more visible (Statistics Finland: 2009:4).

${ }^{9}$ See the introductory chapter by Ulrika Mårtensson. See also, Heikkilä, Knuutila \& Scheinin 2005.

10 Author's translation, original in Finnish: "Uskontopoliittinen tilanne on muuttunut ja Suomi on kansainvälistymisen myötä muuttunut myös uskonnollisesti monikulttuurisemmaksi maaksi.” 
again are becoming partners of public actors though various interest group networks and funding mechanisms associated with them. This shift follows a twofold path. On the one hand, the historically privileged Lutheran and Orthodox Churches are loosening their ties with the state, and, on the other hand, minority religions are coming closer to the state. The development involves changes of the societal and identity positions of the respective organizations towards actors in civil society that are also expected take some responsibility for public welfare. In the following sections these changes will be further explored, with focus specifically on the role of Muslim migrants and communities.

\section{Muslim Immigration}

Finland has been a predominantly Lutheran society since the Reformation in the 1520 s, when Finland was the eastern province of Sweden. In 1809, Finland was annexed to Imperial Russia whereby the Russian Orthodox tsar also became the official head of the church. Being part of the multi-religious Russian Empire did not dramatically change Finland's religious composition or legislation, but rather strengthened the position of the historical Orthodox minority in the eastern part of the country and introduced small Orthodox and other religious minorities in various areas of the country. The history of a permanently settled Muslim presence in Finland goes back to the 1870s, when the first so-called Tatar Muslims arrived in the country from the Nizhni Novgorod region. Although they numbered fewer than one thousand individuals, the Tatars were able to institutionalize and gained formal acceptance as an Islamic organization in 1925 based on the then new Religious Freedom Act, which followed the independence of Finland in December 1917. Tatar immigration ended in the mid 1920s due to the closing of the border with the Soviet Union (Martikainen 2009: 78-83).

Muslim migration remained at low levels until the 1960s, but gradually increased due to work, study and marriage migration. As Finland was a post-war emigration country, there was little labour immigration until the 1980s, and, thus, Finland has no major Muslim labour migrant groups like the many other Northern and Central European countries. Net migration flows to Finland began to increase in the 1980s, and they continued to grow in the following decades. Besides increasing work, study and 
marriage migration, Finland started to accept refugees of the Iran-Iraq war in the late 1980s under the quota administered by the UNHCR. Furthermore, from the early 1990s onwards more people of Muslim background were to arrive, mostly as UNHCR refugees or independent asylum seekers from the conflict-ridden countries of Somalia, former Yugoslavia (Bosnians and Kosovo Albanians) and Afghanistan. As a result, the majority of Finnish Muslims are of recent refugee background, despite the history of Tatars which now extends to the fifth generation (Martikainen 2009: 79).

The number of Muslim immigrants is difficult to estimate, but various attempts have been made. According to my estimate of the religious background of first-generation immigrants (foreign born) in Finland from 1990 to 2009; Christians constituted 61 per cent, Muslims 19 per cent, non-religious 11 per cent, Buddhists 4 per cent, ethnoreligionists 2 per cent and Hindus 1 per cent in 2009 (see Table 1). The share of Muslims has risen over the years, as there were approximately 4,000 first-generation Muslim immigrants in 1990 and 45,000 in 2009. That implies a trebling of Muslims from 6 to 19 per cent among first-generation immigrants. The largest Muslim groups are from Somalia, Iraq, Turkey and former Yugoslavia (Martikainen 2011). Even though this is a rough estimate, it shows that Muslims constitute about one fifth of all immigrants.

\begin{tabular}{|l|r|r|r|r|r|}
\cline { 2 - 6 } \multicolumn{1}{l|}{} & \multicolumn{1}{l|}{1990} & \multicolumn{1}{l|}{1995} & \multicolumn{1}{l|}{2000} & \multicolumn{1}{l|}{2005} & \multicolumn{1}{l|}{2009} \\
\hline Buddhist & $2 \%$ & $2 \%$ & $3 \%$ & $3 \%$ & $4 \%$ \\
\hline Christian & $76 \%$ & $69 \%$ & $66 \%$ & $64 \%$ & $61 \%$ \\
\hline Ethnoreligionist & $1 \%$ & $2 \%$ & $2 \%$ & $2 \%$ & $2 \%$ \\
\hline Hindu & $1 \%$ & $1 \%$ & $1 \%$ & $1 \%$ & $1 \%$ \\
\hline Muslim & $6 \%$ & $14 \%$ & $17 \%$ & $18 \%$ & $19 \%$ \\
\hline Non-religious & $9 \%$ & $10 \%$ & $10 \%$ & $10 \%$ & $11 \%$ \\
\hline Unknown & $4 \%$ & $2 \%$ & $2 \%$ & $1 \%$ & $1 \%$ \\
\hline
\end{tabular}

Table 1. The estimated religious background of first-generation immigrants in Finland from 1990 to 2009, percentages. Source: Martikainen 2011. 
Even though the share of Muslims among immigrants is significant, they are not the largest religious group as Foner and Alba suggest. While this can in part be explained by the lack of postwar (Muslim) labour migration to Finland, it points to a more serious shortcoming of Foner and Alba's analysis, or more precisely of the data on which they rely. European postwar labour immigration relied mainly on three distinct types of sending countries: migration from the neighbouring countries, from former colonies and from other countries via bilateral labour movement agreements. Many, but not all, immigrants arriving via the two latter types were of Muslim background, but much less so from the neighbouring countries. Neighbouring countries, however, often constitute a major share of all immigrants, as in the case of Sweden (Finns), the UK (Irish) and Germany (Italians, Poles, Greeks, etc.) (Castles \& Miller 2009: 97-119). Additionally, many immigrants have not arrived because of work, but due to other reasons, including family reunification, marriage and study, which also bear certain religious characteristics. Pre-migratory selection processes may in some cases lead to overrepresentation of some religious groups among immigrants, if they are overrepresented, for instance, in certain occupations, different social classes or regions dominated by emigration.

However, for a number of reasons, academic research has extensively focused on immigrants arriving from outside Europe, and this selection overemphasizes the role of Muslims as migrants. The large numbers of Christian immigrants have remained outside of the scope of research-including in Finland-and, hence, at the periphery of academic analysis. Considering these Finnish realities, one might question Foner and Alba's view that 'social science literature inevitably reflects the concerns and realities in the societies under study' (Foner \& Alba 2008: 387, emphasis added), at least if we are to gain a comprehensive account of the religious background of immigrants, and the eventual implications for receiving societies. Another reason related to this imbalanced picture is the quality and type of data on which numbers and estimates of Muslims in Europe rely. The figures often aim to provide the maximum number of Muslims living in a certain country, but do not break the numbers into immigrant generations and 
therefore overemphasize the actual numbers of Muslims among immigrants, a category that Muslims are associated with. ${ }^{11}$ Furthermore, the number of other immigrant religions is much less often examined. Foner and Alba's analysis concerning the numbers and actual significance of Muslim immigrants thus appears to miss the target on three accounts. First, on the basis of literature they presume that Muslim immigrants in Europe are the only really significant group, and leave the discussion of other religions to the side. Second, they do not question the numbers or try to compare them with the total number of immigrants. Third, they do not define what constitutes an 'immigrant', which confuses these figures even further.

Foner and Alba are correct in their observation that Muslim immigrants have been studied more intensely than other religiously identified immigrant groups, but by leaving aside the existing and growing literature on other immigrant religions, including studies of Christian, Buddhist, Hindu and other religions, they do not truly engage in a comparative study. A different picture starts to emerge when these other groups are taken into account and the focus is turned to the organizational level. In a comparative study of immigrant congregations in the city of Turku in Finland, which has the country's second largest immigrant population, it was argued that the communities in question provided all the positive aspects that Foner and Alba were describing as typical features of US immigrant religions. These positive aspects were present in all congregations studied, including the Muslim ones. One major difference between this Finnish case and the USA remained though - the congregations were not particularly focusing on general welfare activities, as those were taken care of by the municipality and the state (Martikainen 2004). While this observation may appear somewhat contradictory to the argumentation of this article, it is not necessarily so, because the data was gathered in the early 2000s, and based on ongoing research among the same

\footnotetext{
${ }^{11}$ Problems with estimating the religious background of immigrants are well known, and it makes country comparisons difficult. This was also noted in the introduction of the Yearbook of Muslims in Europe (Nielsen et al., 2009), where the editors deliberately chose not to provide a summary table of the number of Muslims in different countries, even though the book has the best available information on the topic!
} 
communities, increasing levels of co-operation with public authorities can be identified. Moreover, as the historical differences between the USA and Finnish welfare structures are distinctly different, the statement should be understood in that context. Hence, the service structure of the state affects activities on the community level that is related to the religion--state relations to which we shall turn next.

\section{State-Muslim Relations}

The Finnish state views itself as religiously neutral, even though the special historical roles and rights of the Lutheran and Orthodox Churches are recognized. Religious actors are seen as interest groups like any other, and there is no major pressure to change the existing state of affairs. Among others, religious school education in the pupil's own religion is available for many minority religions, and it should be nonconfessional in its nature, as specified by the Religious Freedom Act in 2003. Hence, in the Finnish context religious neutrality does not imply the state's indifference to the religious needs of citizens. Criticism of church/religion and state relations also exists in the form of an increasingly visible New Atheism and among many in the political left, especially in the middle-size party The Green League, but it is more directed at equal treatment than to the total abolition of existing regulations.

The religious institutionalization of the Tatar Muslims in the 1920s was resourced by the community itself, as was the case for all other minority religions as well. Initially, most of the newly organized groups were Protestant Free Churches, but the same regulations applied to the Catholic Church as well as the few non-Christian groups. ${ }^{12}$ As

\footnotetext{
12 In Finland, formal registration is usually a necessary precondition for any voluntary association to function. The organizational forms to which the article refers are those of a 'registered religious community organization' (Finnish, rekisteröity uskonnollinen yhdyskunta) and 'registered association' (Finnish, rekisteröity yhdistys). The former includes a thorough evaluation process and such organizations may be granted specific rights, such as the ability to perform formally approved marriages and the right to have religious education in state schools. The latter is a less demanding process, where the association has the right to have its own finances. Currently, the legislation regarding these two organizational forms is similar. We also need to bear in mind that the formal religious registration process to be recognized as a
} 
the number of Muslims rose rapidly in the 1990s, a wave of Islamic institutionalization followed with the establishment of numerous local mosques and other Muslim societies. Local authorities encouraged these groups to apply for formal recognition as 'religious community organizations' or 'registered associations'. The rationale was that by doing so the groups would be able to apply for municipal support, which was welcome as the majority of new Muslims were of refugee background with few resources of their own. Most local Muslim groups were quick to organize, and hence they gradually became approved as bodies representative of local Muslim interests. By the end of the 1990s, there was a nationwide, state recognized network of mosque and other Islamic associations, but with few stable links between the communities. Local variations notwithstanding, it seems that public authorities and other interested people played a crucial role in this process. In the language of new institutionalism, it was a question of institutional isomorphism, as Muslim activists realized that they were required to set up formal organizations in order to gain public approval (coercive isomorphism) and they also copied each other's strategies (mimetic isomorphism). (Cadge 2008: 351-2) The process illustrates well the importance of the institutional context and how it shapes forms of organization.

The rapid Islamic institutionalization was accompanied by an even more extensive organization of immigrants generally into various kinds of cultural, ethnic, sporting etc. associations taking place around the country during the 1990s. The reasons for this were the same: the need of formal approval and resources. A noteworthy feature of these institutionalization processes was that they touched overwhelmingly people of recent refugee background, many of whom also happened to be Muslim. Compared with the Muslims, other immigrant groups were much less active during the same period. (Pyykkönen 2007a: 72-4) Miikka Pyykkönen (2007a: 116-17) relates these

religion by the state has been conducted only by some religious minority groups, and many smaller communities have in legal terms remained as registered associations. However, many Muslim groups have opted for the deeper regulation to be recognized as a registered religious community organization, and have successfully undergone the process. 
formalization processes to the emergence of project society, whereby immigrant associations since the late 1990s could increasingly become partners in integration projects and thus gain some resources; this development coincided with the largest wave of formal institutionalization. After Finland joined the EU in 1995, projects became a major tool for public administration to develop, create and support immigrant integration activities. With the support of funding, especially, from the European Social Fund and Finland's national lottery fund, The Slot Machine Association, hundreds of local projects have been started, many including immigrant associations as partners. In this way the associational governance embedded in new public management has been a prominent part of the post-1990 immigrant associational life in Finland (Martikainen, Valtonen \& Wahlbeck 2012).

One type of project that some of the Muslim organizations have engaged in is the immigrant integration project. The large and influential mosque communities especially have attempted to gain from this kind of project. Traditionally, as well as in most contemporary cases, the key activities of immigrant religious organizations in Finland focus on cultic and educational activities, in addition to providing a meeting place for social and festive occasions (Martikainen 2004: 225-33). However, the project market, and especially the integration projects, encourages religious organizations to engage in matters that used to be taken care of by the municipality and the state. Drawing on the terminology of Michel Foucault and Mitchell Dean, Miikka Pyykkönen (2007b:201) calls this process the governmentalization of civil society in Finland. It is also worth noticing that while the same processes have affected religious organizations generally in Finland, the circumstance that these public reforms have provided occupational opportunities especially for post-1990 immigrants implies that the impact of new public management has been particularly strong among immigrant associations.

If the 1990 s can be characterized by immigrants' local institutionalization into communities of shared interest, such as mosque communities and women's societies, the 2000s evidence a trend to create local, regional and national pan-ethnic representative bodies that can function as mediators between the public sector and the 
myriad of immigrant, including Muslim, associations. The demand for these came from the public sector, which was at loss as to who should be consulted regarding various issues, but also from entrepreneurial immigrant activists. Several pan-ethnic organizations have thus been founded around Finland, and the state has expanded the range of activities of the Advisory Board for Ethnic Relations (ETNO), an expert body with national and regional boards run by the Finnish Government. ETNO's function is to

(1) Promote interaction between Finland's ethnic minorities and the authorities, NGOs and the political parties in Parliament, equally at the national, regional and local level; and

(2) Provide the ministries with immigration policy expertise in the interests of furthering an ethnically equal and diversified society.

(Ministry of the Interior 2010)

ETNO is a new broker in ethnic and immigration affairs, but an even more important actor is the Ombudsman for Minorities. The Office of the Ombudsman for Minorities was founded in 2002 as part of new legislative and administrative changes related to the implementation of EU anti-discrimination and equality directives, whereby multicultural issues were assigned to the state administration. The first Ombudsman soon realized that many topical issues were related to Muslims, but the state had no interlocutor to represent the Muslim immigrants. This circumstance initiated a process that led to the establishment of the Islamic Council of Finland. The Ombudsman played a central role in the process, by providing legal assistance and helping to raise state funds to the new organization from its beginning (Martikainen 2007). As far as I know, such close state involvement in minority religion affairs has only one historical precedent, the Finnicization of the Orthodox Church in post-independence Finland in the 1920s (Laitila \& Loima 2004: 156-81). 
The emergence of Islam as a concern for the Finnish state can be explained in terms of four main reasons. Firstly, media reporting from elsewhere in Europe and the world has given Islam a problematic reputation among the public, and with post-1990 migration these became also national debates. We should, however, note that public perceptions and social realities do not equate. While a generally negative view of any given subject does not necessarily contribute to anything positive, it is still different from actual behaviour and experiences. As we have seen in the above examples, it can be argued that Finnish public authorities have been highly receptive of Muslim interests, even though it has been a slow learning process. Secondly, many of the less affluent immigrants who are in need of welfare benefits have Muslim religious background, and, thus, Islam has become something to be noted in public administration in association with non-religious social problems. Thirdly, the growing securitization of Islam, especially since 9/11, has forced Finnish authorities to monitor and react to potential terrorist threats in Finland, if only to conform with EU security co-operation. Also, the Finnish Security Police (Supo) has been assigned more resources for counterterrorism surveillance, and the threat of Islamic radicalization did play a role (albeit small) in the Finnish Internal Security Programme of 2008 (Ministry of the Interior 2008: 70-1). Fourth, the very structure of the welfare state itself-old and new-provides ample occasions for contact between the people and the state. Some of these occasions are specifically related to religion.

\section{Islam as a Public Religion in Post-Secular Finland}

José Casanova and Jürgen Habermas are only two among several social theorists and commentators who have noted a new presence of religion in the public sphere. This general observation is also true in Finland, where various forms of religion have gained new prominence not only in public debate and visibility, but also in academic research. Casanova relates the emergence of public religion - or 'deprivatization' - to 'the fact that religious traditions throughout the world are refusing to accept the marginal and privatized role which theories of modernity as well as theories of secularization had reserved for them' (Casanova 1994: 5). In this vein, he refers to political developments 
that gained international importance during the 1980s, especially the Islamic revolution in Iran, the Solidarity movement in Poland, religious developments in Latin America and Protestant fundamentalism in US politics (Casanova 1994: 3).

From the perspective of his philosophical interest in the public sphere and procedures of public debate, Jürgen Habermas has recently become concerned with the significance of public religion in developments towards a new, 'post-secular' society. According to Habermas, post-secularity has three characteristics. First, the relativization of European secularism through globally mediated images 'hinging on religious strife' (Habermas 2008:20) which questions the determinism that established a causal connection between modernity and an ever-more thoroughgoing secularization. Second, religious pluralization, whereby churches and other religious organizations increasingly create their own 'communities of interpretation' (Habermas 2008: 20) in the public arena; the most notable examples being Christian and Muslim fundamentalists. This is related to such publicly debated issues as abortion, same-sex relations, and religious dress. Third, a realization of the permanence of a new, originally Immigrant Other, whose values are traditional and collectivist and strongly associated with religion. For Habermas, postsecularity implies that society remains organized by secular legal institutions and law, which nevertheless are obliged to enable religion to maintain 'a public influence and relevance' (Habermas 2008: 21), which in turn will erode 'the secularist certainty that religion will disappear worldwide in the course of modernization' (Habermas 2008: 21; Habermas 2006).

While these and other internationally recognized religious developments without doubt have played an important role in bringing religion to the fore in the public debate and in research, changes in the global political economy and related transformations in welfare states that began in the 1980s and intensified during the next two decades are certainly important too. The ongoing transformation of the Finnish post-war welfare state has had both intended and unintended consequences. Among the intended consequences are the 
outsourcing of former state services to the private sector and increasing partnerships with 'civil society'. ${ }^{13}$ As noted by Anne Mette Kjær, outsourcing involves a fundamental change in the way things are regulated. As the line of command changes from hierarchical rule by command to policy network steering by reciprocity and trust, the state's capacity to guide results is weakened, even though it still has power via the allocation of resources and the setting of rules (Kjær 2004: 19, 43). Of course Finnish state administrators have not actively been planning to change the existing forms of governance of religion, but what we see is rather the effect of other, broader public policies and general trends which have generated a new state of affairs as a by-product.

To summarize the discussion so far, we can say that the social location of Islam in Finland has transformed as follows (see Table 2). The relationship of Muslim organizations to the state has shifted from neutral and marginal (the Tatars) to an active one (post-1990 immigrant Muslims). The Islamic Council of Finland and several other (policy) networks and platforms have been created as interlocutors with the state. To secure their existence, the state has guaranteed initial funding, hence creating a bond of financial dependence. Muslim organizations are increasingly seen as locations of active citizenship and as arenas of social integration, or at least that would be the preferred state of affairs. A significant force behind this state interest has been the threat of Islamic radicalization and terrorism, forces which, the government hopes, will be tamed and domesticated by active political involvement in decision making. Hence, an ongoing, though currently fairly modest, securitization of Islam has become evident

\footnotetext{
${ }^{13}$ Historically, 'civil society' has not been a central ordering concept in Finnish and Nordic countries, but it is rather an invention of the 1980 s to describe and legitimatize the new roles available for voluntary associations. Despite national differences, the close bond between 'state' and 'society' in the Nordic social democratic tradition has included 'civil society' actors in it, often embedded in the concept of 'society'. The emerging debate of 'civil society' in the $1980 \mathrm{~s}$ has brought in a Tocquevillean understanding of 'civil society' which is in line with neoliberal policies. This differs markedly from the Hegelian tradition that is the historical base for understanding 'civil society' in Finland. For a thorough discussion of the historical development of the concept of 'civil society' in Finland, see: Kettunen 2008: $51-60,140-2$.
} 
during the 2000s. Presumably, Islam's persistently bad public reputation also keeps the administration's concern with security alive; in the Netherlands the intelligence agencies have been arguing since the 1990s that negative public debate about Islam contributes to radicalization among young Muslims, rather than preventing it (Groen \& Kranenberg 2010: 7).

\begin{tabular}{|l|l|l|}
\hline Social location of Islam & Post-war welfare state & $\begin{array}{l}\text { Neoliberalized welfare } \\
\text { state }\end{array}$ \\
\hline Relationship to state & Neutral, marginal & Active, more central \\
\hline State partnerships & None & Growing in numbers \\
\hline Security concerns & None & Very high \\
\hline Public image & Irrelevant and distant & Negative and present \\
\hline
\end{tabular}

Table 2. Changes in the social location of Islam in Finland.

Finnish Islam is definitively a public religion in Casanova's sense of the concept, and Habermas' concept of the post-secular also makes sense of the situation. However, while I am not in fundamental disagreement with Casanova's and Habermas' positions, it is worth pointing out that they both share the view that modernity in its construction is still in force. The arguments of deprivatization, public religion, and post-secularity require the existence of a functionally differentiated society, where the state ultimately also has concerns other than that of a manager and regulator. The state, of course, has not disappeared, but rather changed its ways of functioning and its ethos. Even though the currently pervasive state concern with Islam appears to prove otherwise, it is not necessarily so. If we accept this fundamental transformation of the state's role, it remains difficult to hold any historical institutions as solid as they still appear. Rather, what we should look for are fractures and cracks in its organization, and analyze how deep they are. In this article I do not claim that we have fully entered a new era, but rather that we are living in a liminal phase, where both old and new structures live side by side, but the new order seems to be gaining the upper hand. If Thomas Luckmann's (1999) views on the contemporary social forms of religion are correct, the next step is 
an increasing marketization of religion, of which there are many signs already, as the previous institutional structures are transforming.

\section{Conclusion}

The focus of this article is the institutionalization of Islam in the context of the changing Finnish welfare state. The point of departure is a critique of Nancy Foner and Richard Alba's views of the different receptions of immigrant religions in the USA and Europe. It is argued that Foner and Alba over-emphasized the role of Islam in Europe, and did not compare like with like in their analysis. In this context, I have argued that in so far as classical state-church/religion relations are used as frameworks of analysis, their changing nature must also be considered; Foner and Alba serve as examples of a study that has failed to consider this circumstance and consequently has produced a limited view of what is really happening. In the last section, José Casanova's and Jürgen Habermas' views on contemporary religion were discussed. Even though their respective concepts of 'public religion' and 'post-secular society' inevitably tell us something important about the current state of affairs, it was argued that they rely too much on a taken for granted acceptance of a continuous differentiation of societies as a fundamental aspect of modernity.

This article has brought forward an alternative view for understanding and analysing the position of Muslim minority organizations and their relationship to the Finnish state. While there is a relatively high degree of public interventions, they do only modestly make sense within the framework of historical state-church/religion relations. Rather, they were viewed as examples of the transforming governance of religions that is based on the emergence of a neoliberalized project society. These interventions erode the classical place of a minority religion in Finland, and invite the group in question to participate actively in the construction of social capital and social cohesion for the common good - an activity that the state has increasingly outsourced to civil society.

The role of Islam and Muslim organizations has been, in the case of Finland, that of an accelerant. Already emergent ways of thinking and doing were mobilized as the 
administrative system needed to react. Except for the high-level security concern over radical Islam, there is nothing that makes the Muslim experience different from those of other religions in the country. It actually seems that the social positions of all religions are becoming closer to each other, including the nationally specific Lutheran and Orthodox Churches, and potentially more controversial. It is in this sense that religion has become public and Finland post-secular.

\section{Acknowledgements}

I would like to thank the editors of this special issue and Miikka Pyykkönen for their comments on the manuscript. The article has been written in association with the 'Transnational and Local: The Social Integration of Immigrant Communities' Project, funded by the Academy of Finland (project number 131720).

\section{References}

Alasuutari, Pertti, 2006: "Suunnittelutaloudesta kilpailutalouteen: Miten muutos oli ideologisesti mahdollinen?", in: Risto Heiskala and Eeva Luhtakallio (eds.): Uusi jako: Miten Suomesta tuli kilpailukyky-yhteiskunta?, Gaudeamus, Helsinki.

Arestis, Philip and Sawyer, Malcolm, 2005: "Neoliberalism and the Third Way", in: Alfredo Saad-Filho and Deborah Johnston (eds.): Neoliberalism: A Critical Reader, Pluto Press, London.

Bäckström, Anders and Davie, Grace (eds.), 2010: Welfare and Religion in 21st Century Europe: Volume 1. Configuring the Connections, Ashgate, Farnham.

Bramadat, Paul and Koenig, Matthias (eds.), 2009: International Migration and the Governance of Religious Diversity, McGill-Queen's University Press, Montreal.

Brenner, Neil, Peck, Jamie and Theodore, Nik, 2010: "Variegated Neoliberalization: Geographies, Modalities, Pathways”, in: Global Networks 10, 2: 182-222. 
Byrnes, Timothy A. and Katzenstein, Peter J. (eds.), 2006: Religion in an Expanding Europe, Cambridge University Press, Cambridge.

Cadge, Wendy, 2008: "De Facto Congregationalism and the Religious Organizations of Post-1965 Immigrants to the United States: A Revised Approach", in: Journal of the American Academy of Religion 76, 2: 344-374.

Casanova, José, 2007: "Immigrants and the New Religious Pluralism: A European Union/United States Comparison", in: Thomas Banchoff (ed.): Democracy and the New Religious Pluralism, Oxford University Press, Oxford.

- 1994: Public Religions in the Modern World, The University of Chicago Press, Chicago.

Castles, Stephen and Miller, Mark J., 2009: The Age of Migration: International Population Movements in the Modern World, 4th edition, The Guildford Press, London.

Fetzer, Joel S. and Soper, J. Christopher, 2005: Muslims and the State in Britain, France, and Germany, Cambridge University Press, Cambridge.

Foner, Nancy and Alba, Richard, 2008: "Immigrant Religion in the U.S. and Western Europe: Bridge or Barrier to Inclusion?”, in: International Migration Review 42, 2: 360-392.

Groen, Janny and Kranenberg, Annieke, 2010: Women Warriors for Allah: An Islamist Network in the Netherlands, University of Pennsylvania Press, Philadelphia.

Habermas, Jürgen, 2008: "Notes on a Post-Secular Society", in: New Perspectives Quarterly 25: 17-29.

- 2006: "Religion in the Public Sphere," in: European Journal of Philosophy 12, 1: 125.

Heikkilä, Markku, Knuutila, Jyrki and Scheinin Martin, 2005: "State and Church in Finland", in: Gerhard Robbers (ed.): State and Church in the European Union, 2nd edition, Nomos, Baden-Baden.

Heiskala, Risto, 2006: "Kansainvälisen toimintaympäristön muutos ja Suomen yhteiskunnallinen murros", in: Risto Heiskala and Eeva Luhtakallio (eds.): 
Uusi jako: Miten Suomesta tuli kilpailukyky-yhteiskunta?, Gaudeamus, Helsinki.

Hirschl, Ran, 2004: "The Political Origins of New Constitutionalism," in: Indiana Journal of Global Legal Studies, 11, 1: 71-108.

Kettunen, Pauli, 2008: Globalisaatio ja kansallinen me: Kansallisen katseen historiallinen kritiikki, Vastapaino, Tampere.

Kjær, Anne Mette, 2004: Governance, Polity, Cambridge.

Koenig, Matthias, 2009: "How Nation-states Respond to Religious Diversity", in: Paul Bramadat and Matthias Koenig (eds.): International Migration and the Governance of Religious Diversity, McGill-Queen's University Press, Montreal.

Laitila, Teuvo and Loima, Jyrki, 2004: Nationalism and Orthodoxy: Two Thematic Studies on National Ideologies and their Interaction with the Church, University of Helsinki, Renvall Institute, Helsinki.

Luckmann, Thomas, 1999: “The Religious Situation in Europe: The Background to Contemporary Conversions", in: Social Compass 46, 3: 251-258.

MacGregor, Susanne, 2005: “The Welfare State and Neoliberalism," in Alfredo SaadFilho and Deborah Johnston (eds.): Neoliberalism: A Critical Reader, Pluto Press, London.

Martikainen, Tuomas, 2011: "Maahanmuuttajien uskonnollisen taustan tilastollinen arvioiminen Suomessa", in: Teologinen Aikakauskirja, 116, 3: 232-246.

- 2009: "Finland", in: Göran Larsson (ed.): Islam in the Nordic and Baltic Countries, Routledge, London.

- 2007: "The Governance of Islam in Finland”, in: Temenos 43, 243-265.

- 2004: Immigrant Religions in Local Society: Historical and Contemporary Perspectives in the City of Turku, Åbo Akademi University Press, Åbo.

Martikainen, Tuomas and Gauthier, François (eds), 2013: Religion in the Neoliberal Age: Political Economy and Modes of Governance, Ashgate, Farnham.

Martikainen, Tuomas, Valtonen, Kathleen and Wahlbeck, Östen, 2012: "The Social Integration of Immigrants in Finland", in: Jim Frideres and John Biles (eds): 
International Perspectives: Integration and Inclusion, McGill-Queen's University Press, Montreal.

Maussen, Marcel, 2007: The Governance of Islam in Western Europe: A State of the Art Report. IMISCOE Working Paper No. 16,

http://www.imiscoe.org/publications/workingpapers/documents/GovernanceofI slam.pdf

Ministry of Education, 2001: Uskonnonvapauskomitean mietintö, Komiteanmietintö 2001:1, Opetusministeriö, Helsinki.

Ministry of the Interior, 2010: “Advisory Board for Ethnic Relations ETNO”, (Accessed 2 July 2010),

http://www.intermin.fi/intermin/home.nsf/pages/A6DAD54E3A9379A2C2257 3B50030FDAA?opendocument.

- 2008: Safety First: Internal Security Programme. Government plenary session 8 May 2008, Publications of the Ministry of the Interior 25/2008, Ministry of the Interior, Helsinki.

Nielsen, Jørgen S., Akgönül, Samim, Alibašić, Ahmet, Maréchal, Brigitte and Christian Moe (eds.), 2009: Yearbook of Muslims in Europe, Volume 1, Brill, Leiden.

Pessi, Anne Birgitta, 2010: "The Church as a Place of Encounter: Communality and the Good Life in Finland”, in: Andreas Bäckström and Grace Davie (eds.): Welfare and Religion in 21st Century Europe: Volume 1. Configuring the Connections, Ashgate, Farnham.

Pyykkönen, Miikka, 2007a: "Integrating Governmentality: Administrative Expectations for Immigrant Associations in Finland”, in: Alternatives 32, 197-224.

- 2007b: Järjestäytyvät diasporat: Etnisyys, kansalaisuus, integraatio ja hallinta maahanmuuttajien yhdistystoiminnassa, University of Jyväskylä, Jyväskylä.

Rathgeb, Steven and Smyth, Judith, 2010: "The Governance of Contracting Relationships: 'Killing the Golden Goose' - A Third Sector Perspective”, in: Stephen P. Osborne (ed.): The New Public Governance: Emerging Perspectives on the Theory and Practice of Public Governance, Routledge, London. 
Robbers, Gerhard (ed.), 2005: State and Church in the European Union, 2nd edition, Nomos, Baden-Baden.

Sinha, Subir, 2005: "Neoliberalism and Civil Society: Project and Possibilities", in: Alfredo Saad-Filho and Deborah Johnston (eds.): Neoliberalism: A Critical Reader, Pluto Press, London.

Statistics Finland, 2009: Suomi lukuina 2009, Statistics Finland, Helsinki.

Sulkunen, Pekka, 2006: "Projektiyhteiskunta ja uusi yhteiskuntasopimus", in: Kati Rantala and Pekka Sulkunen (eds.): Projektiyhteiskunnan kääntöpuolia, Gaudeamus, Helsinki. 